\title{
HFE Process Guidance and Standards for Potential Application to Updating NRC Guidance
}

Jacques Hugo

J. J. Persensky

July 2012

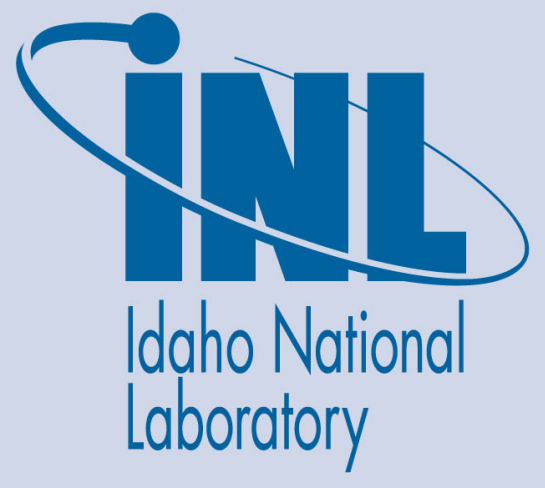

The INL is a U.S. Department of Energy National Laboratory operated by Battelle Energy Alliance 
INL/EXT-12-26539

\title{
HFE Process Guidance and Standards for Potential Application to Updating NRC Guidance
}

\author{
Jacques Hugo
}

J. J. Persensky

July 2012

Idaho National Laboratory
Idaho Falls, Idaho 83415

http://www.inl.gov

Washington, DC 20555 


\title{
HFE Process Guidance and Standards for potential application to updating NRC guidance
}

\author{
Jacques Hugo and J. J. Persensky \\ Idaho National Laboratory
}

\section{BACKGROUND}

For systems to operate safely and effectively, they must be designed to support the people who operate them. It is increasingly recognized in all industries that human factors issues must be considered as an early and central part of development. Experience shows that it is ineffective and risky to address human factors issues as an afterthought. The risks associated with inadequate attention to human factors issues can best be avoided by starting human factors engineering (HFE) activities as early as possible in the design process and continuing the activities throughout the development and implementation process.

Whatever type of system is being developed, the appropriate action is suggested by some underlying principles of good human factors practice. The overall objective should be to ensure that the development process is "human-centered".

The NRC recognizes the crucial role of the human element in nuclear facility design, operation and maintenance for safety. This requires the integration of Human Factors with other engineering disciplines. It cannot be conducted in isolation, and is very dependent on relationships with the large number of other role players who have a stake in the people aspects of usability and capability, and hence a stake in HFE. Best practice is thus only achieved when the principles of human factors are integrated into the mainstream of systems development. From both a quality and a regulatory point of view, HF activities must be shown to influence engineering and other decisions about original designs, operational procedures, procured equipment, and work force and training requirements. NUREG-0711, the Human Factors Engineering Program Review Model, was developed to encourage the application of human factors to the entire development process and is used by thr NRC in their licensing review process.

Good management is needed to address human factors comprehensively. In most cases, the activities of different parts of the development team must be closely coordinated, especially if the system being designed involves human tasks. The international nuclear industry has implemented successful approaches to controlling human factors activities and ensuring that they are integrated with the mainstream of development. It is not only a regulatory requirement, but also industry best practice to implement a rigorous methodology to ensure that human factors 
activities proceed in parallel with technical development and timed to maximize influence on system and plant design.

This summary examines the international standards and guidelines needed for the programs, processes and procedures that must guide this integration within licensee organizations. It also highlights the applicability of particular standards or guidelines to the proposed updates of NUREG-0800, the Standard Review Plan, NUREG-0711 and NUREG-0700, Human-system Interface Design Review Guidelines.

\section{THE NEED FOR HFE PROCESS STANDARDS AND GUIDELINES}

\subsection{REQUIREMENTS FOR A HUMAN FACTORS INTEGRATION PROCESS}

Conducting HFE in nuclear engineering organizations requires a multidisciplinary effort to generate and compile information about human capabilities and limitations and apply that information to functions, structures, systems, components, facilities, procedures, jobs, environments, training, staffing, and personnel management for safe, comfortable, effective human performance.

The core process of HFE is very simple, and is focused on an understanding of human-related issues that might represent risks, requirements or opportunities for the project. Five key processes characterize the integration:

- Identifying and managing human factors issues - this is the driving process

- $\quad$ Supporting analyses - necessary to underpin decisions and plans

- Co-ordination - essential to avoid duplication and mismatch

- Contribution to project outputs - how the value gets added

- Verification of compliance - ensuring that human factors requirements are implemented.

In particular, the HFE process must make provision for the following:

\section{General requirements}

The practical implementation of these processes as a multidisciplinary effort requires a Human Factors Integration process that focuses on:

- Identification and definition of requirements for the interaction between humans and technical system components and environments.

- The analysis and definition of the human activities and processes required to support the technical system. 
- Supporting the design of systems, procedures, jobs and organizations to ensure that they match human capabilities and limitations.

2. Integrating human characteristics into system design to optimize performance within the human/machine system. This includes consideration of the following topics:

- $\quad$ Equipment design

- Workstation/ console design

- Workplace layout

- Maintenance access and ease of maintenance

- $\quad$ Operator interface design (e.g. computing facilities and screen design)

- Function allocation (between humans and automation)

- Interaction among workers

- Working environments (e.g. climate, lighting, noise).

3. Avoiding the safety risks which humans might cause by operating or maintaining the system improperly. This includes processes to assess the effects of, and prevent the consequences of:

- Human reliability and sources of human error

- $\quad$ Effects of misuse or abuse

- External and environmental hazards

4. The short or long term hazards to health resulting from normal operation of the system. This includes processes to assess the effects of, and prevent the consequences of exposure to:

- Nuclear radiation

- Toxic materials

- $\quad$ Electric shock

- Mechanical injury

- $\quad$ Musculoskeletal injury (e.g. heavy lifting; repetitive movement)

- $\quad$ Extreme heat/cold

- Extreme vibration

- Extreme noise

- Optical hazards

- Electro-magnetic radiation

5. Assessment of the number of people required to operate and maintain the system. This includes processes to analyze and make recommendation to other stakeholders in the team on the following:

- $\quad$ Staffing levels

- Workload

- Team organization

- Anthropometric and general physical characteristics

- $\quad$ Knowledge and ability requirements 
- Job specifications

\subsection{INTERNATIONAL HFE PROCESS STANDARDS AND GUIDELINES}

There are several international standards and guidelines that describe how to achieve the integration of human factors in engineering processes. These standards and guidelines all address the following to a greater or lesser degree:

- A life cycle perspective on the application of HFE within a project, from concept onwards

- A common approach for identifying and managing human-related risks and opportunities

- How to undertake the core HFE activities in support of project objectives

- HFE contributions to add value to project outputs

- Guidance on the contribution that can be made by specialist technical activities

- Guidance on coordinating HFE activities with other stakeholders.

The standards discussed below were judged to be the most appropriate to the NRC and licensees' requirements. They all provide guidance on the development and management of the HFE process and the human-system products produced as a result of this process. Two groups of guidelines are included: those directly applicable to nuclear installations, and more generic ones not specifically related to nuclear installations.

\subsection{STANDARDS AND GUIDELINES SPECIFIC TO NUCLEAR POWER PLANTS}

\begin{tabular}{|c|l|l|l|}
\hline No. & \multicolumn{2}{|l|}{ Standard } & $\begin{array}{l}\text { Applicability for update of } \\
\text { NUREGs }\end{array}$ \\
\hline 1 & $\begin{array}{l}\text { IEEE 1023- } \\
1988\end{array}$ & $\begin{array}{l}\text { IEEE Guide for the Application of } \\
\text { Human Factors Engineering to } \\
\text { Systems, Equipment, and Facilities } \\
\text { of Nuclear Power Generating } \\
\text { Stations }\end{array}$ & $\begin{array}{l}\text { Applicable to the management of } \\
\text { the human factors engineering } \\
\text { process, in conjunction with } \\
\text { NUREG-0711 and IEEE 1220-1998. } \\
\text { The combination of NUREG-0711, } \\
\text { IEEE 1023-1988 and IEEE 1220- } \\
\text { 1998 forms the basis of a } \\
\text { methodology that employs sound } \\
\text { system engineering practices in the } \\
\text { management of PBMR's HFE } \\
\text { process. }\end{array}$ \\
\hline
\end{tabular}




\begin{tabular}{|c|c|c|c|}
\hline No. & Standard & & $\begin{array}{l}\text { Applicability for update of } \\
\text { NUREGs }\end{array}$ \\
\hline 2 & $\begin{array}{l}\text { IEEE 1289- } \\
1998\end{array}$ & $\begin{array}{l}\text { IEEE guide for the application of } \\
\text { human factors engineering in the } \\
\text { design of computer-based } \\
\text { monitoring and control displays } \\
\text { for nuclear power generating } \\
\text { stations }\end{array}$ & $\begin{array}{l}\text { Applicable to the design of HSI } \\
\text { displays in conjunction with } \\
\text { NUREG/CR-6633, NUREG/CR- } \\
6634 \text { and NUREG-0700. } \\
\text { The document provides additional } \\
\text { information not covered in NUREG- } \\
0700\end{array}$ \\
\hline 3 & IEC 60964 & $\begin{array}{l}\text { Design of Control Rooms for } \\
\text { Nuclear Power Plants }\end{array}$ & $\begin{array}{l}\text { Applicable to the design of control } \\
\text { rooms. See IEC } 60965 \text { for specific } \\
\text { requirements for the Independent } \\
\text { Shutdown Room. To be read in } \\
\text { conjunction with ISO } 11064 \text {. } \\
\text { The combination of ISO } 11064 \text { and } \\
\text { IEC } 60964 / 5 \text { provides a coherent set } \\
\text { of HF criteria for PBMR control } \\
\text { rooms. }\end{array}$ \\
\hline 4 & IEC 60965 & $\begin{array}{l}\text { Supplementary control points for } \\
\text { reactor shutdown without access to } \\
\text { the main control room }\end{array}$ & $\begin{array}{l}\text { Applicable to the design of the } \\
\text { Independent Shutdown Room. To be } \\
\text { read in conjunction with ISO11064. } \\
\text { As for IEC } 60964\end{array}$ \\
\hline 5 & IEC 61771 & $\begin{array}{l}\text { Control Rooms - Verification and } \\
\text { Validation of Design }\end{array}$ & $\begin{array}{l}\text { Applicable to the verification and } \\
\text { validation of PBMR control rooms. } \\
\text { To be read in conjunction with } \\
\text { NUREG/CR- } 6393 \text {. } \\
\text { Can be used together with } \\
\text { NUREG/CR-6393 to develop V\&V } \\
\text { requirements and plans for } \\
\text { integrated systems. }\end{array}$ \\
\hline 6 & IEC 61839 & $\begin{array}{l}\text { Design of Control Rooms - } \\
\text { Functional Analysis and } \\
\text { Assignment }\end{array}$ & $\begin{array}{l}\text { Applicable to the analysis of } \\
\text { functions related to control rooms. } \\
\text { The document provides valuable } \\
\text { guidance on functional analysis for } \\
\text { control rooms not found in any other } \\
\text { document. As such it can also } \\
\text { provide valuable guidance for the } \\
\text { development of Operating } \\
\text { Descriptions. }\end{array}$ \\
\hline
\end{tabular}




\begin{tabular}{|c|l|l|l|}
\hline No. & \multicolumn{2}{|l|}{ Standard } & $\begin{array}{l}\text { Applicability for update of } \\
\text { NUREGs }\end{array}$ \\
\hline 7 & IEC 62241 & $\begin{array}{l}\text { Main Control Room - Alarm } \\
\text { Functions and Presentation }\end{array}$ & $\begin{array}{l}\text { Applicable to the development of an } \\
\text { alarm philosophy and general } \\
\text { requirements for the presentation of } \\
\text { alarms in the control room. } \\
\text { To be read in conjunction with ISA } \\
18.02 \text { and EEMUA 191. } \\
\text { These three documents provide } \\
\text { important guidance on the } \\
\text { development of comprehensive } \\
\text { alam documentation. They can be } \\
\text { used by all disciplines involved } \\
\text { (HFE, I\&C and Operations). }\end{array}$ \\
\hline
\end{tabular}

\subsection{STANDARDS AND GUIDELINES NOT SPECIFIC TO NUCLEAR POWER PLANTS}

\begin{tabular}{|c|l|l|l|}
\hline No. & \multicolumn{1}{|c|}{ Standard } & \multicolumn{1}{|c|}{ Title } & \multicolumn{1}{|c|}{$\begin{array}{c}\text { Applicability for update of } \\
\text { NUREGs }\end{array}$} \\
\hline 8 & ISA 18.02 & $\begin{array}{l}\text { Management of Alarm Systems for } \\
\text { the Process Industries }\end{array}$ & $\begin{array}{l}\text { Applicable to the development of an } \\
\text { alarm philosophy and general } \\
\text { requirements for the presentation of } \\
\text { alarms in the control room. } \\
\text { To be read in conjunction with IEC } \\
62241 \text { and EEMUA 191. } \\
\text { See item 7 }\end{array}$ \\
\hline 9 & $\begin{array}{l}\text { ISO } \\
10075: 1991\end{array}$ & $\begin{array}{l}\text { Ergonomic principles related to } \\
\text { mental work-load -- General terms } \\
\text { and definitions and Part 2: Design } \\
\text { principles }\end{array}$ & $\begin{array}{l}\text { Applicable to the development of } \\
\text { HF Design Criteria and the analysis } \\
\text { of operator workload (part of Task } \\
\text { Analysis) }\end{array}$ \\
\hline 10 & $\begin{array}{l}\text { ISO } \\
10551: 1995\end{array}$ & $\begin{array}{l}\text { Ergonomics of the thermal } \\
\text { environment -- Assessment of the } \\
\text { influence of the thermal } \\
\text { environment using subjective } \\
\text { judgement scales }\end{array}$ & $\begin{array}{l}\text { Valuable guidance for work } \\
\text { environments where operators may } \\
\text { be subject to thermal stressors. }\end{array}$ \\
\hline
\end{tabular}




\begin{tabular}{|c|c|c|c|}
\hline No. & Standard & Title & $\begin{array}{c}\text { Applicability for update of } \\
\text { NUREGs }\end{array}$ \\
\hline 11 & $\begin{array}{l}\text { ISO } 11064, \\
\text { Part } 1-7\end{array}$ & $\begin{array}{l}\text { Ergonomic design of control } \\
\text { centers }\end{array}$ & $\begin{array}{l}\text { Applicable to Main Control Rooms } \\
\text { and post-event/shutdown facilities } \\
\text { and would be a valuable } \\
\text { enhancement of NUREG- } 0700 \text { as } \\
\text { the standard provides valuable } \\
\text { guidance on the principles of control } \\
\text { center design arrangement of control } \\
\text { suites, control room layout and } \\
\text { control center verification and } \\
\text { validation. }\end{array}$ \\
\hline 12 & $\begin{array}{l}\text { ISO } \\
11226: 2000\end{array}$ & $\begin{array}{l}\text { Ergonomics -- Evaluation of static } \\
\text { working postures }\end{array}$ & $\begin{array}{l}\text { Important guidance for the design of } \\
\text { workspaces, inside the MCR and in } \\
\text { the plant. }\end{array}$ \\
\hline 13 & $\begin{array}{l}\text { ISO } 11228- \\
1: 2003\end{array}$ & $\begin{array}{l}\text { Ergonomics - Manual handling - } \\
\text { Part 1: Lifting and carrying }\end{array}$ & $\begin{array}{l}\text { Important guidance for the design of } \\
\text { workspaces where workers are } \\
\text { exposed to physical hazards. }\end{array}$ \\
\hline 14 & $\begin{array}{l}\text { ISO } \\
11399: 1995\end{array}$ & $\begin{array}{l}\text { Ergonomics of the thermal } \\
\text { environment -- Principles and } \\
\text { application of relevant } \\
\text { International Standards }\end{array}$ & See item $13,21-25$, etc. \\
\hline 15 & $\begin{array}{l}\text { ISO } \\
11428: 1996\end{array}$ & $\begin{array}{l}\text { Ergonomics -- Visual danger } \\
\text { signals -- General requirements, } \\
\text { design and testing }\end{array}$ & $\begin{array}{l}\text { Supplemental guidance for } \\
\text { NUREG-0700 }\end{array}$ \\
\hline 16 & $\begin{array}{l}\text { ISO } \\
11429: 1996\end{array}$ & $\begin{array}{l}\text { Ergonomics -- System of auditory } \\
\text { and visual danger and information } \\
\text { signals }\end{array}$ & $\begin{array}{l}\text { Supplemental guidance for } \\
\text { NUREG-0700 }\end{array}$ \\
\hline 18 & $\begin{array}{l}\text { ISO } 13406- \\
1: 1999\end{array}$ & $\begin{array}{l}\text { Ergonomic requirements for work } \\
\text { with visual displays based on flat } \\
\text { panels -- Part 1: Introduction, and } \\
\text { Part 2: Ergonomic requirements } \\
\text { for flat panel displays }\end{array}$ & $\begin{array}{l}\text { Applicable to the development of } \\
\text { Design Criteria for specific } \\
\text { hardware layouts in control rooms } \\
\text { (e.g. Reactor Protection System } \\
\text { displays). }\end{array}$ \\
\hline 19 & ISO 13407 & $\begin{array}{l}\text { Human-Centered Process for } \\
\text { Interactive Systems }\end{array}$ & $\begin{array}{l}\text { Applicable to the design and } \\
\text { development of all human-system } \\
\text { interfaces. The document is a } \\
\text { general methodological guide to a } \\
\text { human-centered process in al HFE } \\
\text { activities and could be used as } \\
\text { supplemental guidance in NUREG- } \\
0711 \text { (in conjunction with IEEE } \\
\text { 1023) for the development of } \\
\text { integrated HFE processes. }\end{array}$ \\
\hline
\end{tabular}




\begin{tabular}{|c|c|c|c|}
\hline No. & Standard & Title & $\begin{array}{c}\text { Applicability for update of } \\
\text { NUREGs }\end{array}$ \\
\hline 20 & $\begin{array}{l}\text { ISO } \\
13688: 1998 \\
\end{array}$ & $\begin{array}{l}\text { Protective clothing - General } \\
\text { requirements. }\end{array}$ & $\begin{array}{l}\text { General guidance on the use of PPE } \\
\text { in the plant }\end{array}$ \\
\hline 21 & $\begin{array}{l}\text { ISO } 15534- \\
1: 2000\end{array}$ & $\begin{array}{l}\text { Ergonomic design for the safety of } \\
\text { machinery -- Part } 1 \text { : Principles for } \\
\text { determining the dimensions } \\
\text { required for openings for whole- } \\
\text { body access into machinery }\end{array}$ & \multirow[t]{3}{*}{$\begin{array}{l}\text { Important guidance for the design of } \\
\text { workspaces where workers are } \\
\text { exposed to physical hazards. }\end{array}$} \\
\hline 22 & $\begin{array}{l}\text { ISO } 15534- \\
2: 2000\end{array}$ & $\begin{array}{l}\text { Ergonomic design for the safety of } \\
\text { machinery -- Part 2: Principles for } \\
\text { determining the dimensions } \\
\text { required for access openings }\end{array}$ & \\
\hline 23 & $\begin{array}{l}\text { ISO } 15534- \\
3: 2000\end{array}$ & $\begin{array}{l}\text { Ergonomic design for the safety of } \\
\text { machinery -- Part 3: } \\
\text { Anthropometric data }\end{array}$ & \\
\hline 24 & ISO 6385:1981 & $\begin{array}{l}\text { Ergonomic principles in the design } \\
\text { of work systems }\end{array}$ & $\begin{array}{l}\text { General guidance on physical } \\
\text { ergonomics - can be used in } \\
\text { conjunction with NUREG-0700. }\end{array}$ \\
\hline 25 & ISO 7243:1989 & $\begin{array}{l}\text { Hot environments -- Estimation of } \\
\text { the heat stress on working man, } \\
\text { based on the WBGT-index (wet } \\
\text { bulb globe temperature) }\end{array}$ & See item $21-23$ \\
\hline 26 & ISO 7726:1998 & $\begin{array}{l}\text { Ergonomics of the thermal } \\
\text { environment -- Instruments for } \\
\text { measuring physical quantities }\end{array}$ & See item $21-23,25$ \\
\hline 27 & ISO 7730:1994 & $\begin{array}{l}\text { Moderate thermal environments -- } \\
\text { Determination of the PMV and } \\
\text { PPD indices and specification of } \\
\text { the conditions for thermal comfort }\end{array}$ & See item $21-23,25-26$ \\
\hline 28 & ISO 7731:2003 & $\begin{array}{l}\text { Ergonomics - Danger signals for } \\
\text { work places -- Auditory danger } \\
\text { signals }\end{array}$ & See item $21-23,25-27$ \\
\hline 29 & ISO 7933:1989 & $\begin{array}{l}\text { Hot environments -- Analytical } \\
\text { determination and interpretation of } \\
\text { thermal stress using calculation of } \\
\text { required sweat rate }\end{array}$ & See item $21-23,25-28$ \\
\hline 30 & ISO 8996:1990 & $\begin{array}{l}\text { Ergonomics -- Determination of } \\
\text { metabolic heat production }\end{array}$ & See item $21-23,25-29$ \\
\hline
\end{tabular}




\begin{tabular}{|c|c|c|c|}
\hline No. & Standard & Title & $\begin{array}{c}\text { Applicability for update of } \\
\text { NUREGs }\end{array}$ \\
\hline 31 & $\begin{array}{l}\text { ISO } 9241 \text { Parts } \\
1-17\end{array}$ & $\begin{array}{l}\text { Ergonomic requirements for office } \\
\text { work with visual display terminals }\end{array}$ & $\begin{array}{l}\text { NOTE that much of ISO } 9241 \text { is } \\
\text { being updated and renumbered at } \\
\text { present and many improvements are } \\
\text { being made. Some existing parts are } \\
\text { outdated (e.g. parts related to } \\
\text { physical HSI components such as } \\
\text { displays and input devices) and the } \\
\text { updated parts should thus be } \\
\text { consulted for updated NUREG- } \\
0700 \text {. }\end{array}$ \\
\hline 32 & $\begin{array}{l}\text { ISO } 9355- \\
1: 1999\end{array}$ & $\begin{array}{l}\text { Ergonomic requirements for the } \\
\text { design of displays and control } \\
\text { actuators -- Part 1: Human } \\
\text { interactions with displays and } \\
\text { control actuators, and Part 2: } \\
\text { Displays }\end{array}$ & $\begin{array}{l}\text { Applicable to the development of } \\
\text { Design Criteria for specific controls } \\
\text { and displays in control rooms. }\end{array}$ \\
\hline 33 & ISO 9886:1992 & $\begin{array}{l}\text { Evaluation of thermal strain by } \\
\text { physiological measurements }\end{array}$ & See item $21-23,25-30$ \\
\hline 34 & ISO 9920:1995 & $\begin{array}{l}\text { Ergonomics of the thermal } \\
\text { environment -- Estimation of the } \\
\text { thermal insulation and evaporative } \\
\text { resistance of a clothing ensemble }\end{array}$ & See item $21-23,25-30,33$ \\
\hline 35 & ISO 9921:2003 & $\begin{array}{l}\text { Ergonomics - Assessment of } \\
\text { speech communication. }\end{array}$ & $\begin{array}{l}\text { Supplemental guidance for } \\
\text { NUREG-0700 }\end{array}$ \\
\hline 45 & ISO/DIS 15536 & $\begin{array}{l}\text { Ergonomics - computer manikins } \\
\text { and body templates. }\end{array}$ & See item $21-23,25-30,33-34$ \\
\hline 46 & $\begin{array}{l}\text { ISO/IEC } \\
18035: 2003\end{array}$ & $\begin{array}{l}\text { Information technology - Icon } \\
\text { symbols and functions for } \\
\text { controlling multimedia software } \\
\text { applications. }\end{array}$ & $\begin{array}{l}\text { Supplemental guidance for } \\
\text { NUREG-0700 }\end{array}$ \\
\hline 47 & $\begin{array}{l}\text { ISO/PAS } \\
18152: 2003\end{array}$ & $\begin{array}{l}\text { Ergonomics of human-system } \\
\text { interaction - Specification for the } \\
\text { process assessment of human- } \\
\text { system issues. }\end{array}$ & $\begin{array}{l}\text { To be used in conjunction with ISO } \\
13407 \text { and ISO } 18529 \text { for guidance } \\
\text { in NUREG- } 0711 \text { for development of } \\
\text { human-centered systems } \\
\text { development processes. This might } \\
\text { also be used for Supplemental } \\
\text { guidance in NUREG-0800 and } 0711 \\
\text { on integration of human factors in } \\
\text { the Systems Engineering Process. }\end{array}$ \\
\hline
\end{tabular}




\begin{tabular}{|c|c|c|c|}
\hline No. & Standard & Title & $\begin{array}{c}\text { Applicability for update of } \\
\text { NUREGs }\end{array}$ \\
\hline 48 & $\begin{array}{l}\text { ISO/TR } \\
16982: 2002\end{array}$ & $\begin{array}{l}\text { Ergonomics of human-system } \\
\text { interaction -- Usability methods } \\
\text { supporting human-centered design }\end{array}$ & $\begin{array}{l}\text { To be used in conjunction with ISO } \\
9241-11\end{array}$ \\
\hline 49 & $\begin{array}{l}\text { ISO/TR } \\
18529: 2000\end{array}$ & $\begin{array}{l}\text { Ergonomics -- Ergonomics of } \\
\text { human-system interaction -- } \\
\text { Human-centered lifecycle process } \\
\text { descriptions }\end{array}$ & $\begin{array}{l}\text { To be used in conjunction with ISO } \\
13407 \text { and ISO } 18152 \text { for guidance } \\
\text { in NUREG-0711 for development of } \\
\text { human-centered systems } \\
\text { development processes. See also } \\
\text { item } 47\end{array}$ \\
\hline 50 & $\begin{array}{l}\text { ISO/TS 13732- } \\
2: 2001\end{array}$ & $\begin{array}{l}\text { Ergonomics of the thermal } \\
\text { environment -- Methods for the } \\
\text { assessment of human responses to } \\
\text { contact with surfaces -- Part 2: } \\
\text { Human contact with surfaces at } \\
\text { moderate temperature }\end{array}$ & $\begin{array}{l}\text { See item } 21-23,25-30,33-34 \text {, } \\
45\end{array}$ \\
\hline 51 & $\begin{array}{l}\text { ISO/TS } \\
16071: 2003\end{array}$ & $\begin{array}{l}\text { Ergonomics of human-system } \\
\text { interaction - Guidance on } \\
\text { accessibility for human-computer } \\
\text { interfaces }\end{array}$ & $\begin{array}{l}\text { Important guidance on accessibility } \\
\text { - should be added to NUREG- } 0800 \\
\text { and }-0700\end{array}$ \\
\hline 52 & $\begin{array}{l}\text { ISO/IEC } 9216 \\
\text { Part } 1-4\end{array}$ & $\begin{array}{l}\text { Information Technology - } \\
\text { Software Product Quality }\end{array}$ & $\begin{array}{l}\text { For reference only in NUREG-0700 } \\
\text { and - } 0711 \text {. This standard deals with } \\
\text { software quality in the software } \\
\text { engineering life cycle. It has a } \\
\text { section on usability (referred to as } \\
\text { "quality in use") and thus overlaps } \\
\text { with ISO 9241-11. }\end{array}$ \\
\hline 53 & $\begin{array}{l}\text { ISO/PAS } \\
20282 \text { Part } 1- \\
4\end{array}$ & $\begin{array}{l}\text { Ease of operation of everyday } \\
\text { products }\end{array}$ & $\begin{array}{l}\text { Important supplemental guidance on } \\
\text { usability of commercial products, } \\
\text { including metrics and usability } \\
\text { testing. Although it is aimed at } \\
\text { consumer products, the principles } \\
\text { are equally applicable to industrial } \\
\text { HSIs. }\end{array}$ \\
\hline
\end{tabular}

